
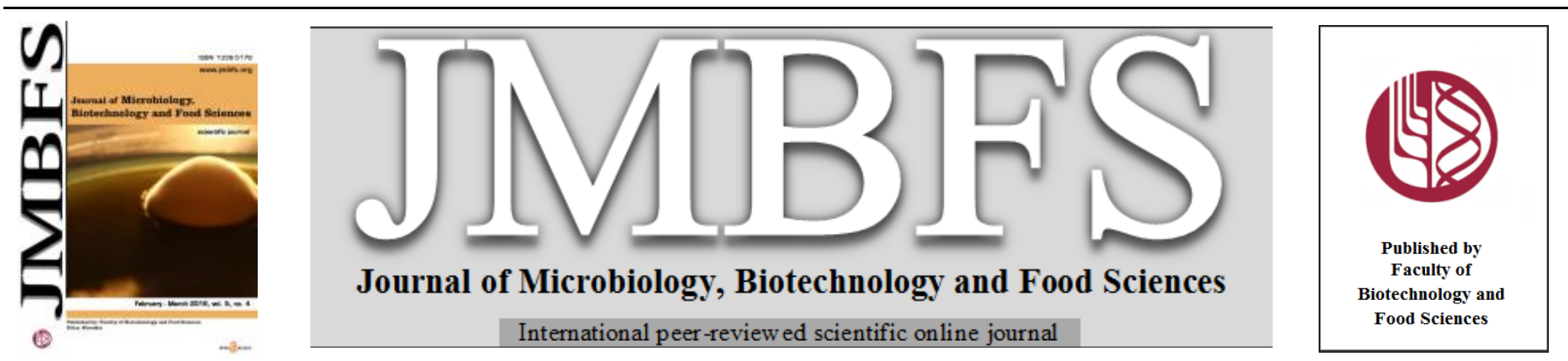

\title{
IMPROVED SHELF LIFE OF BROWN RICE BY HEAT AND MICROWAVE TREATMENT
}

\author{
King B. Bergonio I, , Leny Grace G. Lucatin ${ }^{2}$, Gerome A. Corpuz ${ }^{2}$, Nerissa C. Ramos ${ }^{1}$, and Joy Bartolome A. Duldulao
}

\author{
$\operatorname{Address}(e s)$ : \\ ${ }^{1}$ Rice Chemistry and Food Science Division, Philippine Rice Research Institute, Science City of Muñoz 3119, Nueva Ecija, Philippines \\ ${ }^{2}$ Department of Chemistry, College of Arts and Sciences, Central Luzon State University, Science City of Muñoz 3120 , Nueva Ecija, Philippines
}

*Corresponding author: kingbbergonio@yahoo.com.ph

doi: $10.15414 / j m b f s .2016 .5 .4 .378-385$

\section{ARTICLE INFO}

Received 18.5. 2015

Revised 13. 11. 2015

Accepted 4. 12. 2015

Published 1. 2. 2016

Regular article OPEN $\partial_{\text {ACCESS }}$

\begin{abstract}
Widespread marketing and consumption of brown rice is limited by its short shelf life. This study aimed to address this problem by establishing treatments to stabilize brown rice against rancidity, while retaining its antioxidants, for subsequent commercial applications. Three types of treatments, namely dry heat $\left(\mathrm{DH}\right.$, oven at $\left.60^{\circ} \mathrm{C}\right)$, wet heat $(\mathrm{WH}$, steam), and microwave (MW, 800 watts), with different exposure times were tested. Lipase activity was determined for all treatments. Samples were monitored for 0, 4 and 6 months for changes in free fatty acids, antioxidant activity, and total phenolics content; while $0,2,4$ and 8 months for changes in raw and cooked sensory attributes.

Treatments with longer exposure effectively inactivated lipase enzyme and consequently reduced free fatty acid release, even up to 6 months of storage. Total phenolics content of treated and untreated samples were not significantly different after treatment, but tended to increase during storage. Similar trend was observed on the antioxidant activity of DH treated brown rice, except that of MW and WH treated sample. Initial raw and cooked sensory attributes of treated and untreated samples were comparable. A significant downshift on the raw (aroma, glossiness and off-odor) and cooked (aroma, off-odor and off-taste) sensory attribute scores and acceptability of both untreated and treated brown rice were noted beginning second month, except that of treatments with longer exposure namely DH $25 \mathrm{~min}$, MW 90sec and WH 90sec, including MW 60sec. Only treated brown rice samples with longer exposure times (DH 25min, MW 90sec and WH 90sec), including MW 60sec, remained acceptable by the fourth month, and even up to eight months of storage.
\end{abstract}

Keywords: Brown rice; shelf life; heat treatment; microwave treatment; lipase inactivation

\section{INTRODUCTION}

Consumption of whole grain cereals like brown rice helps reduce risks of chronic diseases. One of the whole grain cereals is brown rice. It is more nutritious than milled (polished) rice. Approximately $80 \%$ of the minerals and $15 \%$ of proteins are taken out when brown rice is milled. A significant amount (68\% to $90 \%)$ of calcium, phosphorus, riboflavin, and thiamine are removed (Dykes and Rooney, 2007). Brown rice is a good source of dietary fiber and antioxidant compounds such as phenolic acids.

Brown rice is also economically important in the Philippines where rice selfsufficiency and supply stability are targeted. Having 10-percentage point milling recovery advantage over milled rice, brown rice can greatly contribute to rice self-sufficiency. Additionally, energy consumption in processing of brown rice is 50-60\% lower than milled rice (Cuyno, 2003), because polishing and whitening steps are eliminated. Despite its nutritional and economic benefits, brown rice is still not widely consumed and marketed because of its susceptibility to rancidity. The short shelf life of brown rice (2-3 months) is attributed to the rapid reactions of the lipase enzyme, which are released from the breakup of the bran cells during the hulling process, with the lipids in the bran to produce free fatty acids. Hence, brown rice requires suitable storage condition and/or effective control.

Heat treatments have been employed to inactivate lipolytic enzymes in cereals and cereal products, but results have been inconclusive (Rose et al., 2008). Vetrimani and Haridas Rao, (1990) and Haridas Rao et al., (1980) found that heating wheat bran at $175^{\circ} \mathrm{C}$ for $40 \mathrm{~min}$ increased its shelf life from 20 to 90 days and heating wheat germ at $150^{\circ} \mathrm{C}$ for $25 \mathrm{~min}$ increased shelf life from 15 to 180 days, respectively. On the other hand, Cuendet et al., (1954) found autoclave treatment not effective in increasing the shelf life of whole wheat flour, while Lehtinen et al., (2003) found that the complete inactivation of lipase in oats by extrusion resulted in greater lipid oxidation. As cited by Rose $\boldsymbol{e t}$ al., (2008), authors from the two later studies theorized that the increase in lipid oxidation was a result of destruction of antioxidants during heat treatment. Maintaining antioxidants is therefore an important consideration in stabilization of cereals and cereal products.
Several approaches have been utilized to stabilize brown rice against lipolytic hydrolysis. One approach is by inactivating lipase by heating rough rice with moist gas to obtain stabilized products (Van Ata $\boldsymbol{e t}$ al., 1952) or by parboiling or precooking (McCabe, 1976). Another approach is by removing the kernel oil, which serves as the substrate for lipase, through organic solvent extraction (Kester, 1951). Finally, by denaturation and inactivation of lipase and lipaseproducing bacteria and mold by liquid ethanol (Champange et al., 1991) and ethanol vapors (Champange and Hron, 1992). However, one drawback to the two latter techniques is the use of chemical solvents that may be harmful to health and the environment.

Likewise, various methods of brown rice storage conditions have been tested to determine the temperature, atmosphere, and kind of packaging material that could improve its shelf life. Storage at low temperature, storage under modified atmospheres such as carbon dioxide, storage under vacuum, storage using polyethylene and nylon films and aluminum pouch, or the combination of different storage conditions and packaging materials have been reported to improve the shelf life of brown rice. However, these storage conditions and packaging materials are costly, hence, may not be suitable for commercial applications.

In effort to address the shelf life problem of brown rice, this study aimed to determine treatment condition for dry and wet heat, and microwave treatment that could stabilize brown rice against lipolytic rancidity during storage, while retaining its antioxidants, for subsequent commercial applications.

\section{MATERIAL AND METHODS}

\section{Brown rice preparation}

Aromatic and low amylose-gelatinization temperature type rice, Maligaya Special 8 (MS8), previously reported by Corpuz et al., (2010) as one of the most acceptable varieties for brown rice consumption, was used in this study. MS8 rough rice sample was obtained from the Income Generation Office of the Philippine Rice Research Institute (PhilRice). Rough rice sample was dehulled using Satake ${ }^{\circledR}$ rice dehuller (Satake Engineering, Tokyo, Japan) to obtain brown 
rice. Undehulled and immature grains and other impurities were removed manually before subjecting to different treatments.

\section{Brown rice treatment and storage}

One kilogram of brown rice was subjected, in duplicate, to three different types of treatment, as follows: dry heat (DH) for 15, 20 and 25 min using $30 \times 20 \times 3$ $\mathrm{cm}$ (length $\mathrm{x}$ width $\mathrm{x}$ thickness) $150 \mu \mathrm{m}$ screen sieve in an oven (Yamato, Japan) set at $60^{\circ} \mathrm{C}$; microwave (MW) treatment for 30,60 and $90 \mathrm{sec}$ using a $30 \mathrm{~cm} x$ $20 \mathrm{~cm} \times 10 \mathrm{~cm}$ (length $\mathrm{x}$ width $\mathrm{x}$ thickness) rectangular microwavable plastic container in an 800 Watts and $2450 \mathrm{MHz}$ commercial microwave oven

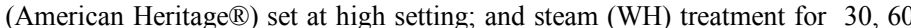
and $90 \mathrm{sec}$ using $30 \times 20 \times 3 \mathrm{~cm}$ (length $\mathrm{x}$ width $\mathrm{x}$ thickness) $150 \mu \mathrm{m}$ screen sieve over a pot of boiling water using a household steamer. These treatments showed no objectionable change in overall appearance compared with untreated brown rice.

Immediately after treatment, samples were placed separately in an aluminum tray and allowed to cool for about $30 \mathrm{~min}$. About $10 \mathrm{~g}$-portion of each sample was obtained, pulverized using Cyclotec ${ }^{\circledR}$ sample mill (Tecator, Sweden), and analyzed for moisture content using Method 44-19 (AACC International, 2000) After 24 hours of equilibration, each sample were placed in a separate polyethylene plastic bag and stored together in a metal box at room temperature and ambient humidity. Another 10 g-portion of each sample was obtained, pulverized, and analyzed for lipase activity and moisture content prior to storage. An untreated brown rice was used as control. Moisture content of the brown rice samples immediately after treatment (after $30 \mathrm{~min}$ of cooling) progressively decrease ranging from $10.75 \%$ to $11.81 \%$, but not on $\mathrm{WH}$ treated sample excep that of WH $30 \mathrm{sec}$. While moisture content after $24 \mathrm{hr}$ of equilibration at room temperature ranged from $11.35 \%$ to $11.91 \%$, which are acceptable levels for storage (data not shown). Temperature and relative humidity during storage ranged from $28-311^{\circ} \mathrm{C}$ and $42-64 \%$, respectively.

Different exposure times were tested to determine optimum treatment condition for each type of treatment that would effectively reduce lipase activity to consequently stabilize brown rice from rancidity during storage. Mild treatments were employed to maintain important antioxidant compounds such as phenolic acids and to retain physically indistinguishable from the untreated brown rice. Preliminary trials conducted by DH treatment at temperature of $65^{\circ} \mathrm{C}$ and above for 15-20 min using oven (Yamato DN-83, Japan) resulted in fissuring and discoloration of the brown rice grains (data not shown). Thus, oven temperature at $60^{\circ} \mathrm{C}$ was employed to inactivate lipase enzymes and different $\mathrm{DH}$ treatment were at varied times ( 0 to $25 \mathrm{~min}$ ). Rothe, (1967) as cited by Juliano, (1985) reported that the inactivation temperature for lipase enzyme in rice bran at $14 \%$ moisture was $55^{\circ} \mathrm{C}$, hence $60^{\circ} \mathrm{C}$ oven treatment may be sufficient for lipase inactivation. For WH treatment, exposure for $100 \mathrm{sec}$ and above under steam resulted in discoloration, while microwave treatment for $100 \mathrm{sec}$ and above caused popping of some of the brown rice grains.

\section{Chemical analysis}

The effect of different treatments in lipase activity of the brown rice samples was determined. Changes in free fatty acids level, total phenolics content, and antioxidant activity were monitored for $0,2,4$ and 6 months of storage at room temperature and ambient humidity using prescribed procedures. All chemical analyses were done in duplicate.

\section{Lipase activity}

Lipase activity was measured using the copper soap assay according to the procedure of Rose and Pike, (2006). About $3 \mathrm{~g}$ of each ground sample was partially defatted with hexane $(1: 10 \mathrm{wt} / \mathrm{vol})$ for $30 \mathrm{~min}$ on a mechanical shaker. Residual hexane was allowed to evaporate at room temperature (about $10 \mathrm{~min}$ ), and $1 \mathrm{~g}$ of the ground, partially defatted sample was weighed into separate tubes (blank and sample). Olive oil $(0.8 \mathrm{~mL})$ and distilled water $(0.15 \mathrm{~mL})$ was added on both tubes and were mixed vigorously. The test tube with the blank was immediately extracted using a stepwise procedure. Five mililiters of hexane were added, mixed using vortex, and then centrifuged at $2000 \mathrm{rpm}$ for $3 \mathrm{~min}$ using benchtop centrifuge (Clay and Adams, NJ). The hexane was decanted into centrifuge tube and the extraction was repeated twice. The hexane extracts were pooled, and evaporated using a water bath at $40^{\circ} \mathrm{C}$, and the residue was redissolved in $4 \mathrm{~mL}$ of isooctane. The test tube with the sample was capped and incubated for $4 \mathrm{hr}$ at $40^{\circ} \mathrm{C}$. After incubation, the test tube with the sample was extracted using hexane as described in the blank. One mililiter of $5 \%(\mathrm{wt} / \mathrm{vol}$.) cupric acetate (adjusted to $\mathrm{pH} 6.1$ with pyridine) was added and then shaken vigorously for $1 \mathrm{~min}$. Afterwards the tubes were centrifuged at $2000 \mathrm{rpm}$ for 1 min and the absorbance was read at $715 \mathrm{~nm}$ using UV-Vis spectrophotometer (Hitachi U-3200, Japan). The absorbance of the sample was compared with the absorbance of oleic acid standard solutions prepared in isooctane $(1-10 \mathrm{mM})$ Lipase activity was expressed as units per gram $\left(\mathrm{U} \mathrm{g}^{-1}\right)$, where $1 \mathrm{U}$ is defined as the micromoles of fatty acid liberated per hour.

$$
L A=1000 * \frac{(4+V) *(A f-A i)}{s t l s}
$$

Where $1000=$ conversion factor from mol. $\mathrm{L}^{-1}$ to $\mu$ equiv $\mathrm{mL}^{-1}, 4=$ volume of isooctane used to redissolve lipids $(\mathrm{mL}), \mathrm{V}=$ volume of olive oil added $(\mathrm{mL})$, $\mathrm{Af}=$ absorbance of sample after incubation at $715 \mathrm{~nm}, \mathrm{Ai}=$ absorbance of blank after incubation at $715 \mathrm{~nm}, \varepsilon=$ molar absorptivity of oleic acid at $517 \mathrm{~nm}\left(\mathrm{M}^{-1}\right.$ $\left.\mathrm{cm}^{-1}\right), \mathrm{t}=$ incubation time $(\mathrm{h}), 1=$ path length $(1 \mathrm{~cm}$ for a standard cuvette), $\mathrm{s}=$ mass of sample $(\mathrm{g})$.

\section{Free fatty acids}

Lipid degradation during storage as free fatty acids was quantified using the rapid colorimetric method of Kwon and Rhee, (1986). One gram of ground brown rice sample was weighed into test tube and the lipids were immediately extracted similar with the procedure by Rose and Pike, (2006). One $\mathrm{ml}$ of 5\% (wt/vol.) cupric acetate (adjusted to $\mathrm{pH} 6.1$ with pyridine) was added to the extract and then shaken vigorously for $1 \mathrm{~min}$. Afterwards the tubes were centrifuged at 2000 rpm for $1 \mathrm{~min}$ and the absorbance was read at $715 \mathrm{~nm}$ using UV-Vis spectrophotometer (Hitachi U-3200, Japan). The sample absorbance was compared with the absorbance of oleic acid standard solutions prepared in isooctane $(1-10 \mathrm{mM})$.

\section{Antioxidant activity (DPPH radical scavenging)}

Free radical scavenging capacity of the samples was estimated using 2, 2' dipheny-1-picrylhydrazyl (DPPH) radical according to the procedure of Iqbal $\boldsymbol{e}$ al., (2005). One gram ground sample was weighed into $15-\mathrm{mL}$ centrifuge tube Ten mililiters of methanol was then added, shaken for 12 hours, and centrifuged at $2000 \mathrm{rpm}$ for 15 minutes. The supernatant was collected, diluted up to $25 \mathrm{~mL}$ with distilled water, and stored at $4^{\circ} \mathrm{C}$, until analysis.

An aliquot of the sample extract ( $3 \mathrm{~mL}$ ) was added to freshly prepared $0.10 \mathrm{mM}$ solution of DPPH $(30 \mathrm{~mL})$ and allowed to stand for $90 \mathrm{~min}$. The absorbance of the DPPH-sample extract mixture was then measured at $517 \mathrm{~nm}$ using UV-Vis spectrophotometer (Hitachi U3200, Japan). The DPPH radical scavenging activity was calculated as follows:

\section{$\%$ DPPH radical scavenging activity $\left.=\underline{\left(A_{b}-A_{s}\right.}\right) \times 100$}

$A_{b}$

Where: $A_{s}=$ absorbance of the sample and $A_{b}=$ absorbance of the blank

\section{Total phenolics content}

The total concentration of phenolic acids (soluble and bound) was determined as gallic acid equivalents (GAE) using the Folin-Ciocalteau procedure as cited by Adom and Liu, (2002).

Extraction of soluble phenolics. Ten mililiters of $80 \%$ (vol/vol) ethanol was added to $1.0 \mathrm{~g}$ of ground sample. The mixture was shaken for $15 \mathrm{~min}$, centrifuged at $2000 \mathrm{rpm}$ for $15 \mathrm{~min}$, and the supernatant was collected. The residue was reextracted with $80 \%$ ethanol twice. The supernatants were combined and the residues were set aside for bound phenolics extraction. The pooled supernatants were oven-dried at $30^{\circ} \mathrm{C}$. After drying, the residue was re-dissolved up to 25.0 $\mathrm{mL}$ with distilled water and then store at $4^{\circ} \mathrm{C}$, until analysis.

Extraction of bound phenolics. For bound phenolics extraction, the residue was digested for one hour with $25 \mathrm{ml}$ of $2.0 \mathrm{~N} \mathrm{NaOH}$ with constant shaking using a mechanical shaker. The mixture was then neutralized with an appropriate amount of $6 \mathrm{M} \mathrm{HCl}$ and was defatted twice with hexane. The final solution was extracted five times with $30 \mathrm{~mL}$ ethyl acetate. The ethyl acetate portion was collected and oven-dried at $30^{\circ} \mathrm{C}$. The residue was re-dissolved up to $25.0 \mathrm{ml}$ with distilled water and then stored at $4^{\circ} \mathrm{C}$, until analysis.

Determination of total phenolics content. Five hundred microliters $(500 \mu \mathrm{L})$ of each extract (soluble and bound) was added with $2.5 \mathrm{~mL}$ of Folin-Ciocalteau's phenol reagent (1/10 dilution). It was allowed to stand temperature for $15 \mathrm{~min}$ at room and then $2.0 \mathrm{~mL}$ of $7.5 \%$ sodium carbonate was added. After 1 hour of color development, the absorbance of the mixture was measured at $765 \mathrm{~nm}$ against a blank and gallic acid standards $\left(0-100 \mu \mathrm{g} \mathrm{mL}^{-1}\right)$. Phenolics content was calculated based on the standard and values were expressed in gallic acid equivalents per gram sample $\left(\mathrm{GAE} \mathrm{g}^{-1}\right)$.

$$
\text { Phenolics acid content }\left(\mathrm{GAE} \mathrm{g}^{-1}\right)=\frac{\mathrm{A} \times 25}{\text { Wt. of samples }(\mathrm{g}) \times \mathrm{MW}_{\mathrm{GA}}}
$$

Where $\mathrm{A}=\mu \mathrm{g} \mathrm{g}^{-1}$ gallic acid based on calibration curve and $\mathrm{MW}_{\mathrm{GA}}=$ gram equivalents of gallic acid $\left(170.2 \mathrm{~g} \mathrm{eq}^{-1}\right)$. Total phenolics acid content was then calculated by adding the contents of soluble and bound forms.

\section{Sensory evaluation}


Sensory evaluation was conducted at the Sensory Laboratory of the Rice Chemistry and Food Science Division, PhilRice, Science City of Muñoz, Nueva Ecija, Philippines. Raw (aroma, off-odor, color, gloss, and translucency) and cooked (aroma, off-odor, gloss, cohesiveness, tenderness, off-taste, and taste) sensory attributes and acceptability were evaluated for $0,2,4$, and 8 months of storage by trained internal panels. Attribute intensities and general acceptability were rated using $15-\mathrm{cm}$ unstructured scaled score cards. The scales were anchored at each end: the left side of the scale corresponded to the lowes intensity $(0 \mathrm{~cm})$ and the right side to the highest intensity (value $15 \mathrm{~cm}$ ) of the sensory attribute.

Cooked brown rice was prepared by addition of water to brown rice (1:2 brown rice to water), washing the brown rice for two times by swirling and replacing same amount of decanted water with fresh tap water, soaking the brown rice with water for $25 \mathrm{~min}$, and cooking using 2-cup capacity electric rice cooker (National, Japan) until the audible switches turned off. Raw and cooked brown rice samples were presented to the sensory panels in a blind and randomized 3 digit coded manner for evaluation. None of the staff involved in the study participated as panellist.

\section{Statistical analysis}

Analysis of variance (ANOVA) was conducted to detect differences between treatments at $p<0.05$ level. When a significant treatment differences was observed, treatment means were separated using Tukey's honesty significant difference (HSD) test. Statistical analyses of physicochemical and sensory evaluation data were performed using SAS ver. 9.1 for Windows (New York, USA) and STATA ver. 12.1(Texas, USA) software, respectively.

\section{RESULTS AND DISCUSSION}

\section{Effects of different treatments on brown rice}

\section{Effects in lipase activity and free fatty acids content}

Inactivation of lipase enzyme, which catalyzes the hydrolysis of lipids (oil) to produce oxidizable fatty acids that are further converted into carbonyl compounds contributing off-odor and off-taste, is primarily considered in prolonging the shelf life of brown rice. All treated brown rice had significantly lower lipase activity compared with untreated sample (Table 1). Increasing exposure time progressively decrease lipase activity of the brown rice, except that of MW treatment where MW 60sec treatment had lower lipase activity than MW $90 \mathrm{sec}$, but were not statistically significant. Most brown rice samples within each treatment type had comparable lipase activity, except that of DH treatment. For each type of treatment, lowest lipase activity was noted in DH $25 \mathrm{~min}$ at $0.29 \mathrm{U}$ $\mathrm{g}^{-1}$, MW $60 \mathrm{sec}$ at $0.31 \mathrm{U} \mathrm{g}^{-1}$, and WH $90 \mathrm{sec}$ at $0.31 \mathrm{U} \mathrm{g}^{-1}$.

Table 1 Lipase activity and free fatty acid content of brown rice samples at different treatments

\begin{tabular}{|c|c|c|}
\hline Sample & $\begin{array}{c}\text { Lipase Activity } \\
\left(\mathbf{U ~ g ~ g}^{-1}\right)\end{array}$ & $\begin{array}{c}\text { Free Fatty Acid Content } \\
\left(\text { mmole } \mathbf{g}^{-1}\right)\end{array}$ \\
\hline Control & $0.45^{\mathrm{e}}$ & $2.57^{\mathrm{g}}$ \\
\hline DH $10 \mathrm{~min}$ & $0.36^{\mathrm{d}}$ & $2.44^{\mathrm{f}}$ \\
\hline DH $15 \mathrm{~min}$ & $0.34^{\text {cd }}$ & $2.36^{\mathrm{e}}$ \\
\hline $\mathrm{DH} 25 \mathrm{~min}$ & $0.29^{\mathrm{a}}$ & $2.33^{\mathrm{e}}$ \\
\hline MW 30sec & $0.33^{\text {bcd }}$ & $2.24^{\mathrm{cd}}$ \\
\hline MW $60 \mathrm{sec}$ & $0.31^{\mathrm{ab}}$ & $2.18^{\mathrm{ab}}$ \\
\hline MW $90 \mathrm{sec}$ & $0.33^{\mathrm{bc}}$ & $2.17^{\mathrm{ab}}$ \\
\hline WH 30sec & $0.34^{\text {bcd }}$ & $2.27^{\mathrm{d}}$ \\
\hline WH 60sec & $0.32^{\mathrm{abc}}$ & $2.13^{\mathrm{a}}$ \\
\hline WH $90 \mathrm{sec}$ & $0.31^{\mathrm{ab}}$ & $2.20^{\mathrm{bc}}$ \\
\hline
\end{tabular}

Means within a column with same letters are not significantly different $(\alpha=0.05)$

All treated brown rice samples had significantly lower free fatty acids content than untreated sample. Increasing treatment exposure of brown rice decreases its lipase activity and consequently reduces its free fatty acids level. MW and WH treated samples have significantly lower free fatty acids content even compared with DH treated brown rice. Free fatty acids level of MW and WH treated brown rice ranged from 2.17-2.24 mmole $\mathrm{g}^{-1}$ and $2.13-2.27$ mmole $\mathrm{g}^{-1}$, respectively; while DH treated brown rice ranged from 2.33-2.44 mmole $\mathrm{g}^{-1}$. This indicates that MW and WH treatments are more effective in inactivating lipase enzymes than DH treatment. This is likely because proteins such as enzymes are more stable against denaturation in a dry environment compared with a wet environment (Damodara, 1996). Likewise, Krugger and Reed, (1988) and Vertimani and Haridas Rao, (1990) as cited by Rose et al., (2008) reported difficulty of decreasing lipase activity of wheat flour using dry heat treatment than wet heat and microwave treatments.
The consistent significant decrease in lipase activity and free fatty acids level of treated compared with untreated brown rice (control) confirmed the effectiveness of heat and microwave treatments in inactivating lipase enzymes. Several researchers have utilized heat and microwave treatments to stabilize cereals and cereal products, but limited studies have been conducted for its direct application for brown rice stabilization. Most of the studies on brown rice shelf life improvement or stabilization focused on the use of different storage temperature and packaging materials (Sharp and Timme, 1986), storage under modified atmospheres (Ory et al., 1980; Santroprete, 1980), treatment by ethanol vapors (Champange and Hron, 1992), and utilization of an antioxidant or chelator (Champange and Hron, 1993; Champange and Grimm, 1995).

\section{Effects in total phenolic content and antioxidant activity}

Mild treatments employed on brown rice samples aimed to maintain inherent antioxidant compounds such as phenolic acids present that could help inhibit reactive oxygen species (peroxides) that causes rancidity. The presence of these indigenous antioxidants in cereals such as brown rice has a marked effect on the onset of non-enzymatic oxidation due to their capability to quench these reactive molecular species into non-reactive form (Lehtinen and Laakso, 2004). This could eventually help improve the storability or shelf life of brown rice. Total phenolic content of all treated brown rice samples did not vary significantly upon treatment (Table 2). Likewise, no significant change was observed on the antioxidant activity of DH treated brown rice compared with untreated sample, except that of MW and WH treated sample. This coincides with the findings of Rose, et al., (2008) on the effect of dry heat treatment on the antioxidant activity of wheat flour. On the other hand, contrary to the findings of Rose, et al., (2008), a significant increase in antioxidant activity was noted on MW and WH treated samples. The increase in antioxidant activity on MW and WH treated samples may be attributed to the slight (not significant) increase in total phenolics content in the sample from 2.86 GAE g${ }^{-1}$ (untreated) to up to $3.41 \mathrm{GAE} \mathrm{g}^{-1}$ (WH 60sec), previously noted. Conversely, DH treated brown rice also increase (not significant, $p>0.0$ ) in total phenolic content, but antioxidant activity did not change. Hence, the increase might be attributed to the type of treatment employed on the brown rice. Oufnac et al., (2006) as cited by Dar and Sharma, (2011) reported that with rise in extraction temperature more phenolic compounds are released. Likewise, according to Afoakwah et al., (2012), microwave radiation causes disruption of hydrogen bonds which enhance penetration of the solvent into the matrix, allowing dissolution of the components to be extracted. Although exposure of brown rice to $\mathrm{MW}$ or $\mathrm{WH}$ treatments were not during the extraction process of antioxidants but were employed prior to the analysis, microwave radiation or steam treatments might have caused hydrolysis of other antioxidant compounds present in the sample resulting in the increase of their extractability, thus, higher antioxidant activity by DPPH radical scavenging analysis.

Table 2 Total phenolics content and antioxidant activity of brown rice samples at different treatments

\begin{tabular}{lcc}
\hline Sample & $\begin{array}{c}\text { Total Phenolics Content } \\
\left(\text { Gallic Acid Equivalent } \mathbf{g}^{-1}\right)\end{array}$ & $\begin{array}{c}\text { Antioxidant Activity } \\
(\% \text { DPPH Inhibition) }\end{array}$ \\
\hline Control & $2.86^{\mathrm{a}}$ & $40.45^{\mathrm{a}}$ \\
DH 10 min & $3.11^{\mathrm{a}}$ & $41.66^{\mathrm{a}}$ \\
DH 15 min & $3.11^{\mathrm{a}}$ & $40.55^{\mathrm{a}}$ \\
DH 25 min & $3.08^{\mathrm{a}}$ & $40.77^{\mathrm{a}}$ \\
MW 30 sec & $3.05^{\mathrm{a}}$ & $54.45^{\mathrm{c}}$ \\
MW 60 sec & $3.24^{\mathrm{a}}$ & $54.65^{\mathrm{c}}$ \\
MW 90 sec & $2.90^{\mathrm{a}}$ & $51.67^{\mathrm{bc}}$ \\
WH 30sec & $3.08^{\mathrm{a}}$ & $51.21^{\mathrm{bc}}$ \\
WH 60sec & $3.41^{\mathrm{a}}$ & $51.63^{\mathrm{bc}}$ \\
WH 90 sec & $3.39^{\mathrm{a}}$ & $49.62^{\mathrm{b}}$ \\
\hline Means within a column with same letters are not significantly different $(\alpha=0.05)$
\end{tabular}

\section{Effects in raw and cooked sensory attributes}

Evaluation by panels perceived no significant change in all raw and cooked sensory attribute scores between treated brown rice and untreated sample (Table 3 and Table 4). However, for each type of treatment, slight increase (not significant) in raw aroma on $\mathrm{DH}$ and $\mathrm{WH}$ treated samples was perceived by panellists attributed to the release of some aromatic compounds such as 2-acetly1-pyrroline from the grains caused by heat treatment. On the other hand, raw aroma of MW treated samples was perceived similar with the untreated raw brown rice. Similarly with raw aroma attribute, an increase (not significant) in raw glossiness scores on $\mathrm{DH}$ and $\mathrm{WH}$ treated samples, while a decrease (not significant) on MW treated brown rice were observed. General acceptability scores of raw and cooked samples ranged from 8.5 to 10.7 and 7.8 to 9.9 , respectively. Raw brown rice (untreated and treated) was perceived no off-odor, moderately intense in color, translucent, slightly glossy, and satisfactory general acceptability (liked moderately). For cooked brown rice sample (untreated and treated), assessment by the panelists revealed slight (faint) aroma; no off-odor; 
moderate glossy, cohesive, and tender; slightly tasty and no off-taste and; very satisfactory general acceptability (liked).

Table 3 Sensory attribute of raw brown rice samples at different treatments

\begin{tabular}{|c|c|c|c|c|c|c|}
\hline \multirow{2}{*}{ Sample } & \multicolumn{6}{|c|}{ Raw Sensory Attribute, Mean Score } \\
\hline & Aroma $^{1}$ & Off-Odor ${ }^{2}$ & Color (brown) ${ }^{3}$ & Gloss $^{4}$ & Translucency $^{5}$ & General Acceptability $^{6}$ \\
\hline Control & $1.2^{\mathrm{a}}$ & $0.0^{\mathrm{a}}$ & $6.5^{\mathrm{a}}$ & $3.6^{\mathrm{abc}}$ & $12.8^{\mathrm{a}}$ & $9.3^{\mathrm{a}}$ \\
\hline DH 10 min & $1.7^{\mathrm{a}}$ & $0.0^{\mathrm{a}}$ & $4.9^{\mathrm{a}}$ & $4.9^{\mathrm{abc}}$ & $12.3^{\mathrm{a}}$ & $9.0^{\mathrm{a}}$ \\
\hline DH 15 min & $1.8^{\mathrm{a}}$ & $0.0^{\mathrm{a}}$ & $4.8^{\mathrm{a}}$ & $5.2^{\mathrm{bc}}$ & $12.8^{\mathrm{a}}$ & $10.0^{\mathrm{a}}$ \\
\hline DH $25 \mathrm{~min}$ & $1.9^{\mathrm{a}}$ & $0.0^{\mathrm{a}}$ & $5.8^{\mathrm{a}}$ & $4.9^{\mathrm{abc}}$ & $12.4^{\mathrm{a}}$ & $8.5^{\mathrm{a}}$ \\
\hline MW 30sec & $1.0^{\mathrm{a}}$ & $0.3^{\mathrm{a}}$ & $5.8^{\mathrm{a}}$ & $3.8^{\mathrm{abc}}$ & $12.4^{\mathrm{a}}$ & $10.0^{\mathrm{a}}$ \\
\hline MW $60 \mathrm{sec}$ & $1.0^{\mathrm{a}}$ & $0.5^{\mathrm{a}}$ & $5.2^{\mathrm{a}}$ & $2.8^{\mathrm{a}}$ & $12.0^{\mathrm{a}}$ & $9.2^{\mathrm{a}}$ \\
\hline MW $90 \mathrm{sec}$ & $1.3^{\mathrm{a}}$ & $0.2^{\mathrm{a}}$ & $6.2^{\mathrm{a}}$ & $2.9^{\mathrm{ab}}$ & $12.2^{\mathrm{a}}$ & $9.8^{\mathrm{a}}$ \\
\hline WH 30sec & $1.3^{\mathrm{a}}$ & $0.5^{\mathrm{a}}$ & $6.4^{\mathrm{a}}$ & $3.9^{\mathrm{abc}}$ & $12.9^{\mathrm{a}}$ & $10.7^{\mathrm{a}}$ \\
\hline WH 60sec & $2.8^{\mathrm{a}}$ & $0.0^{\mathrm{a}}$ & $5.4^{\mathrm{a}}$ & $5.6^{\mathrm{c}}$ & $11.9^{\mathrm{a}}$ & $9.6^{\mathrm{a}}$ \\
\hline WH $90 \mathrm{sec}$ & $2.5^{\mathrm{a}}$ & $0.0^{\mathrm{a}}$ & $4.7^{\mathrm{a}}$ & $5.0^{\mathrm{abc}}$ & $12.1^{\mathrm{a}}$ & $8.8^{\mathrm{a}}$ \\
\hline
\end{tabular}

Means within a column with same letters are not significantly different $(\alpha=0.05)$

${ }^{1} 0=$ none; $3.75=$ slightly aromatic; $7.5=$ moderately aromatic; $11.25=$ aromatic; $15=$ very aromatic

${ }^{2} 0=$ none; $3.75=$ slightly perceptible; $7.5=$ moderately perceptible; $11.25=$ perceptible $; 15=$ very perceptible

${ }^{3} 0=$ weak; $3.75=$ slightly intense; $7.5=$ moderately intense; $11.25=$ intense; $15=$ very intense

${ }^{4} 0=$ dull; $3.75=$ slightly glossy; $7.5=$ moderately glossy; $11.25=$ glossy; $15=$ very glossy

${ }^{5} 0=$ opaque; $3.75=$ slightly chalky; $7.5=$ chalky; $11.25=$ white belly; $15=$ translucent

${ }^{6} 0=$ dislike extremely; $3.75=$ like slightly; $7.5=$ like moderately; $11.25=$ like; $15=$ like extremely

Table 4 Sensory attribute of cooked brown rice samples at different treatments

\begin{tabular}{|c|c|c|c|c|c|c|c|c|}
\hline \multirow{2}{*}{ Sample } & \multicolumn{8}{|c|}{ Cooked Sensory Attribute, Mean Score } \\
\hline & Aroma $^{1}$ & Off-odor $^{2}$ & Gloss $^{3}$ & Cohesiveness $^{4}$ & Tenderness $^{5}$ & Taste $^{6}$ & Off-taste $^{7}$ & General Acceptability $^{8}$ \\
\hline Control & $4.7^{\mathrm{a}}$ & $0.0^{\mathrm{a}}$ & $7.0^{\mathrm{ab}}$ & $6.8^{\mathrm{a}}$ & $5.7^{\mathrm{a}}$ & $3.7^{\mathrm{a}}$ & $0.3^{\mathrm{a}}$ & $9.8^{\mathrm{a}}$ \\
\hline DH $10 \mathrm{~min}$ & $3.6^{\mathrm{a}}$ & $0.2^{\mathrm{a}}$ & $6.8^{\mathrm{ab}}$ & $6.5^{\mathrm{a}}$ & $6.1^{\mathrm{a}}$ & $2.7^{\mathrm{a}}$ & $0.0^{\mathrm{a}}$ & $8.0^{\mathrm{a}}$ \\
\hline DH 15 min & $3.2^{\mathrm{a}}$ & $0.0^{\mathrm{a}}$ & $6.6^{\mathrm{ab}}$ & $6.8^{\mathrm{a}}$ & $5.5^{\mathrm{a}}$ & $2.9^{\mathrm{a}}$ & $0.0^{\mathrm{a}}$ & $8.9^{\mathrm{a}}$ \\
\hline DH 25 min & $3.6^{\mathrm{a}}$ & $0.0^{\mathrm{a}}$ & $7.8^{\mathrm{ab}}$ & $9.0^{\mathrm{a}}$ & $7.7^{\mathrm{a}}$ & $3.0^{\mathrm{a}}$ & $0.0^{\mathrm{a}}$ & $9.5^{\mathrm{a}}$ \\
\hline MW 30sec & $4.5^{\mathrm{a}}$ & $0.0^{\mathrm{a}}$ & $8.5^{\mathrm{ab}}$ & $8.1^{\mathrm{a}}$ & $7.9^{\mathrm{a}}$ & $3.6^{\mathrm{a}}$ & $0.2^{\mathrm{a}}$ & $9.9^{\mathrm{a}}$ \\
\hline MW $60 \mathrm{sec}$ & $3.4^{\mathrm{a}}$ & $0.0^{\mathrm{a}}$ & $6.1^{\mathrm{a}}$ & $8.4^{\mathrm{a}}$ & $6.1^{\mathrm{a}}$ & $3.4^{\mathrm{a}}$ & $0.2^{\mathrm{a}}$ & $8.2^{\mathrm{a}}$ \\
\hline MW $90 \mathrm{sec}$ & $3.5^{\mathrm{a}}$ & $0.0^{\mathrm{a}}$ & $7.5^{\mathrm{ab}}$ & $7.4^{\mathrm{a}}$ & $4.9^{\mathrm{a}}$ & $3.3^{\mathrm{a}}$ & $0.0^{\mathrm{a}}$ & $8.0^{\mathrm{a}}$ \\
\hline WH 30sec & $3.6^{\mathrm{a}}$ & $0.0^{\mathrm{a}}$ & $7.5^{\mathrm{ab}}$ & $7.8^{\mathrm{a}}$ & $5.0^{\mathrm{a}}$ & $2.9^{\mathrm{a}}$ & $0.6^{\mathrm{a}}$ & $7.8^{\mathrm{a}}$ \\
\hline WH 60sec & $4.0^{\mathrm{a}}$ & $0.0^{\mathrm{a}}$ & $8.3^{\mathrm{ab}}$ & $7.1^{\mathrm{a}}$ & $6.6^{\mathrm{a}}$ & $2.9^{\mathrm{a}}$ & $0.0^{\mathrm{a}}$ & $8.3^{\mathrm{a}}$ \\
\hline WH $90 \mathrm{sec}$ & $5.6^{\mathrm{a}}$ & $0.0^{\mathrm{a}}$ & $9.3^{\mathrm{b}}$ & $8.1^{\mathrm{a}}$ & $6.4^{\mathrm{a}}$ & $3.1^{\mathrm{a}}$ & $0.3^{\mathrm{a}}$ & $9.1^{\mathrm{a}}$ \\
\hline
\end{tabular}

Means within a row with same letters are not significantly different $(\alpha=0.05)$

${ }^{1} 0=$ none; $3.75=$ slightly aromatic $; 7.5=$ moderately aromatic; $11.25=$ aromatic; $15=$ very aromatic

${ }^{2} 0=$ none; $3.75=$ slightly perceptible; $7.5=$ moderately perceptible; $11.25=$ perceptible; $15=$ very perceptible

${ }^{3} 0=$ dull; $3.75=$ slightly glossy; $7.5=$ moderately glossy; $11.25=$ glossy; $15=$ very glossy

${ }^{4} 0=$ separated; $3.75=$ slightly cohesive $; 7.5=$ moderately cohesive; $11.25=$ cohesive; $15=$ very cohesive

${ }^{5} 0=$ hard; $3.75=$ slightly tender; $7.5=$ moderately tender; $11.25=$ tender; $15=$ very tender

${ }^{6} 0=$ bland; $3.75=$ slightly tasty; $7.5=$ moderately tasty; $11.25=$ tasty; $15=$ very tasty

${ }^{7} 0=$ none; $3.75=$ slightly perceptible; $7.5=$ moderately perceptible; $11.25=$ perceptible; $15=$ very perceptible

${ }^{8} 0=$ dislike extremely; $3.75=$ like slightly; $7.5=$ like moderately; $11.25=$ like; $15=$ like extremely

Changes on physicochemical properties and sensory attributes during storage

\section{Changes in free fatty acids content}

Changes in free fatty acids content of the samples for up to six months of storage is presented in Figure 2. A steady significant increase in free fatty acids level of each treated and untreated brown rice samples was noted during storage, but increase was significantly lower in treated brown rice. Ory et al., (1980) reported that free fatty acids level of stored brown rice steadily increased throughout the storage period. A considerable abrupt increase in free fatty acids level occurring from two to four months was observed similar with the findings by Ramenzanzadeh et al., (1999) on rice bran. Throughout the storage period, all treated brown rice samples have significantly lower free fatty acid content compared with the untreated brown rice consistent with the lipase activity from the initial analysis (month 0). Lower free fatty acids generation of the samples could be attributed to the reduction of lipase activity caused by different treatments. Effectiveness of lipase inactivation through dry and wet (steam) heat and microwave treatment to subsequently stabilize brown rice against lipolytic rancidity was evident. Hence, this could indicate improvement in storability or shelf life of brown rice samples through these treatments. Treatments with longer exposure times, namely DH 25min, MW 90sec, and WH 90sec were noted to have significantly lowest free fatty acids level after six months of storage.

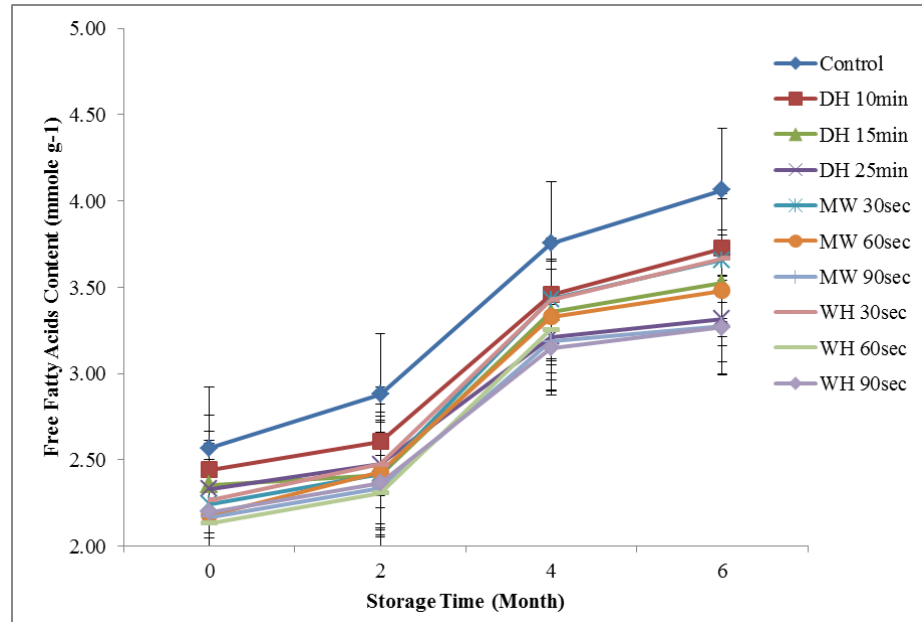

Figure 1 Free fatty acid content of brown rice samples at different treatments during storage 


\section{Changes in total phenolics content and antioxidant activity}

Changes in total phenolics content was monitored only on samples with longer exposure times namely DH 25min, MW 90sec and WH 90sec since findings on the first month (Month 0) revealed no significant effect of different treatments on the total phenolics content of the brown rice sample. Statistical analysis showed a significant increase in total phenolics content on both treated and untreated brown rice sample from 0 to 2 months, and started to plateau after 2 months of storage (Table 5). Total phenolics content of the samples during 0 month ranged from 2.86 to $3.39 \mathrm{GAE} \mathrm{g}^{-1}$; while starting from 2 months up to 6 months of storage, total phenolics content ranged from 4.14 to $5.52 \mathrm{GAE} \mathrm{g}^{-1}$. This trend on the increase in total phenolics content during storage is similar to the findings of Tsugita $\boldsymbol{e t}$ al., (1983) as cited by Juliano, (1985) in rice grain. Tsugita $\boldsymbol{e t}$ al. (1983) proposed that bound phenolic acids are released by enzymatic and nonenzymatic reaction during storage to form free phenolic acids.

Table 5 Total phenolics content of brown rice samples at different treatments during storage

\begin{tabular}{|c|c|c|c|c|}
\hline \multirow[b]{2}{*}{ Treatment } & \multicolumn{4}{|c|}{ Total Phenolics Content (Gallic Acid Equivalent $\mathbf{g}^{-1}$ )* } \\
\hline & Month 0 & Month 2 & Month 4 & Month 6 \\
\hline Control & $2.86^{\mathrm{a}(\mathrm{a})}$ & $4.14^{\mathrm{a}(\mathrm{b})}$ & $4.20^{\mathrm{a}(\mathrm{b})}$ & $5.52^{\mathrm{a}(\mathrm{c})}$ \\
\hline DH $25 \mathrm{~min}$ & $3.08^{\mathrm{a}(\mathrm{a})}$ & $4.23^{\mathrm{a}(\mathrm{b})}$ & $4.70^{\mathrm{a}(\mathrm{bc})}$ & $5.15^{\mathrm{a}(\mathrm{c})}$ \\
\hline MW $90 \mathrm{sec}$ & $2.90^{\mathrm{a}(\mathrm{a})}$ & $4.31^{\mathrm{a}(\mathrm{b})}$ & $4.60^{\mathrm{a}(\mathrm{b})}$ & $5.11^{\mathrm{a}(\mathrm{b})}$ \\
\hline WH $90 \mathrm{sec}$ & $3.39^{\mathrm{a}(\mathrm{a})}$ & $5.72^{\mathrm{b}(\mathrm{b})}$ & $4.58^{\mathrm{a} \mathrm{(ab)}}$ & $5.49^{\mathrm{a}(\mathrm{b})}$ \\
\hline
\end{tabular}

Means within a column with same inscriptions are not significantly different $(\alpha=0.05)$

*Letters inside parenthesis indicate comparison within a row

Similar with the observation on total phenolics content, antioxidant activity of the brown rice samples also increase during storage (Table 6). The increase in DHHP radical scavenging activity may be attributed to the observed increase in total phenolics content of the samples, hence phenolics acids are known to exhibit antioxidative property. A consistent significant increase in antioxidant activity was noted on untreated and DH treated brown rice samples, except that of DH $25 \mathrm{~min}$. During the initial months (month 0 to month 2), antioxidant activity of the untreated and DH treated samples (40.45 to $53.47 \%$ ) were relatively lower than that of MW and WH treated brown rice (49.62 to $62.12 \%$ ). After 2 months of storage, antioxidant activity of untreated and DH treated brown rice abruptly increase having its peak at month 6 . Treatments with shorter exposure time (DH 10min, DH 15min and WH 30sec) had comparable antioxidant activity with the untreated brown rice, except that of MW treated brown rice after 6 months of storage. For MW and WH treated samples, a significant increase in antioxidant activity was observed from 0 to 2 months of storage and started to plateau up to 4 months, except that of MW 30sec; but decrease at 6 months of storage, except that of WH $60 \mathrm{sec}$.

Table 6 Antioxidant activity of brown rice samples at different treatments during storage

\begin{tabular}{|c|c|c|c|c|}
\hline \multirow[b]{2}{*}{ Treatment } & \multicolumn{4}{|c|}{ Antioxidant Activity (\%DPPH Inhibition)* } \\
\hline & Month 0 & Month 2 & Month 4 & Month 6 \\
\hline Control & $40.45^{\mathrm{a}(\mathrm{a})}$ & $53.47^{\mathrm{b}(\mathrm{b})}$ & $70.19^{\mathrm{cd}(\mathrm{c})}$ & $76.22^{\mathrm{d}(\mathrm{d})}$ \\
\hline DH $10 \mathrm{~min}$ & $41.66^{\mathrm{a}(\mathrm{a})}$ & $52.12^{\mathrm{ab}(\mathrm{b})}$ & $66.89^{\mathrm{abc}(\mathrm{c})}$ & $73.15^{\mathrm{cd}(\mathrm{d})}$ \\
\hline DH 15 min & $40.55^{\mathrm{a}(\mathrm{a})}$ & $49.46^{\mathrm{a}(\mathrm{b})}$ & $63.58^{\mathrm{a}(\mathrm{c})}$ & $72.15^{\text {bcd (d) }}$ \\
\hline DH $25 \mathrm{~min}$ & $40.77^{\mathrm{a}(\mathrm{a})}$ & $52.30^{\mathrm{ab}(\mathrm{b})}$ & $64.72^{\mathrm{ab}(\mathrm{c})}$ & $63.49^{\mathrm{a}(\mathrm{c})}$ \\
\hline MW 30sec & $54.45^{\mathrm{c}(\mathrm{a})}$ & $61.49^{\mathrm{c}(\mathrm{b})}$ & $69.71^{\mathrm{cd}(\mathrm{c})}$ & $67.92^{\mathrm{abc}(\mathrm{c})}$ \\
\hline MW $60 \mathrm{sec}$ & $54.65^{\mathrm{c}(\mathrm{a})}$ & $62.12^{\mathrm{c}(\mathrm{ab})}$ & $67.31 \mathrm{a}^{\mathrm{bc}(\mathrm{b})}$ & $64.43^{\mathrm{ab}(\mathrm{b})}$ \\
\hline MW $90 \mathrm{sec}$ & $51.67^{\text {bc (a) }}$ & $61.68^{\mathrm{c}(\mathrm{b})}$ & $65.07^{\mathrm{ab}(\mathrm{b})}$ & $63.19^{\mathrm{a}(\mathrm{b})}$ \\
\hline WH 30sec & $51.21^{\text {bc (a) }}$ & $55.15^{\mathrm{b}(\mathrm{a})}$ & $65.61^{\mathrm{ab}(\mathrm{b})}$ & $69.51^{\text {abcd (b) }}$ \\
\hline WH 60sec & $51.63^{\text {bc (a) }}$ & $61.96^{\mathrm{c}(\mathrm{b})}$ & $71.30^{\mathrm{d}(\mathrm{c})}$ & - \\
\hline WH $90 \mathrm{sec}$ & $49.62^{\mathrm{b}(\mathrm{a})}$ & $61.87^{\mathrm{c}(\mathrm{b})}$ & $69.23^{\mathrm{cd}(\mathrm{c})}$ & $65.85^{\mathrm{abc}(\mathrm{bc})}$ \\
\hline
\end{tabular}

\section{Changes in raw and cooked sensory attributes}

Raw and cooked sensory attributes were monitored to assess and compare the quality changes and storability of treated and untreated brown rice samples during storage in addition to monitoring of their physicochemical changes. Sensory evaluation of raw brown rice samples showed a significant decrease in mean scores on aroma and glossiness; while a significant increase in off-odor in both untreated and treated raw brown rice sample during storage (Table 7). Progressive decrease in aroma scores was consistently comparable for each sample throughout the storage period; similar with glossiness scores, except that of DH 25min, MW 60sec, MW 90 sec and WH $30 \mathrm{sec}$. For raw off-odor attribute, a significant increase was perceived on the samples during the second month with the untreated brown rice as the most off-odored sample; but not on $\mathrm{DH} 10 \mathrm{~min}$, DH 25min, MW 60sec and MW 90sec. By the fourth month, a significantly strong and moderate perceptible off-odor were noticed on untreated sample (10.2 score) and DH treated brown rice (5.8 to 5.9 score), respectively, except that of DH 25min; signifying deterioration. These deteriorated samples were then not subjected to the succeeding session of sensory evaluation. MW and WH treated brown rice, including DH $25 \mathrm{~min}$ treated sample, had significantly lower off-odor scores compared with untreated sample indicative of improvement in storage stability. General acceptability scores of the samples significantly decrease beginning second month of storage, except that of treatments with longer exposure namely DH 25min, MW 90sec and WH 90sec, including MW 60sec. By the fourth month, only treated brown rice sample with longer exposure times (DH 25min, MW 90sec and WH 90sec), including MW 60sec, remained acceptable (liked moderately) even up to eight months of storage. This demonstrates that these treated brown rice had superior storability over the untreated sample.

Table 7 Sensory attribute of raw brown rice samples at different treatments during storage

\begin{tabular}{|c|c|c|c|c|c|c|c|c|c|c|}
\hline \multirow{2}{*}{$\begin{array}{l}\text { Sensory } \\
\text { Attributes }\end{array}$} & \multicolumn{10}{|c|}{ Sample, Mean Score } \\
\hline & Control & DH 10min & DH 15min & DH 25min & MW 30sec & MW 60sec & MW 90sec & WH 30sec & WH 60sec & WH 90sec \\
\hline \multicolumn{11}{|l|}{ Aroma $^{1}$} \\
\hline Month 0 & $1.2^{\mathrm{a}}$ & $1.7^{\mathrm{b}}$ & $1.8^{\mathrm{b}}$ & $1.9^{\mathrm{b}}$ & $1.0^{\mathrm{a}}$ & $1.0^{\mathrm{a}}$ & $1.3^{\mathrm{b}}$ & $1.3^{\mathrm{b}}$ & $2.8^{\mathrm{b}}$ & $2.5^{\mathrm{b}}$ \\
\hline Month 2 & $0.5^{\mathrm{a}}$ & $0.3^{\mathrm{a}}$ & $0.3^{\mathrm{a}}$ & $0.6^{\mathrm{a}}$ & $0.7^{\mathrm{a}}$ & $0.5^{\mathrm{a}}$ & $0.3^{\mathrm{ab}}$ & $0.3^{\mathrm{a}}$ & $0.3^{\mathrm{a}}$ & $0.5^{\mathrm{a}}$ \\
\hline Month 4 & $0.1^{\mathrm{a}}$ & $0.6^{\mathrm{ab}}$ & $0.1^{\mathrm{a}}$ & $0.3^{\mathrm{a}}$ & $0.1^{\mathrm{a}}$ & $0.6^{\mathrm{a}}$ & $0.4^{\mathrm{ab}}$ & $0.5^{\mathrm{ab}}$ & $0.7^{\mathrm{a}}$ & $0.4^{\mathrm{a}}$ \\
\hline Month 8 & - & - & - & $0.0^{\mathrm{a}}$ & - & $0.0^{\mathrm{a}}$ & $0.1^{\mathrm{a}}$ & - & - & $0.1^{\mathrm{a}}$ \\
\hline
\end{tabular}




\begin{tabular}{|c|c|c|c|c|c|c|c|c|c|c|}
\hline Month 0 & $0.0^{\mathrm{a}}$ & $0.0^{\mathrm{a}}$ & $0.0^{\mathrm{a}}$ & $0.0^{\mathrm{a}}$ & $0.3^{\mathrm{a}}$ & $0.5^{\mathrm{a}}$ & $0.2^{\mathrm{a}}$ & $0.5^{\mathrm{a}}$ & $0.0^{\mathrm{b}}$ & $0.0^{\mathrm{a}}$ \\
\hline Month 2 & $3.6^{\mathrm{b}}$ & $1.2^{\mathrm{a}}$ & $2.0^{\mathrm{b}}$ & $1.5^{\mathrm{ab}}$ & $2.6^{\mathrm{b}}$ & $1.6^{\mathrm{a}}$ & $1.2^{\mathrm{a}}$ & $3.0^{\mathrm{b}}$ & $2.6^{\mathrm{a}}$ & $2.1^{\mathrm{b}}$ \\
\hline Month 4 & $10.2^{\mathrm{c}}$ & $5.9^{\mathrm{b}}$ & $5.8^{\mathrm{c}}$ & $3.1^{\mathrm{bc}}$ & $1.8^{\mathrm{ab}}$ & $2.1^{\mathrm{a}}$ & $0.8^{\mathrm{a}}$ & $1.1^{\mathrm{a}}$ & $1.8^{\mathrm{a}}$ & $0.8^{\mathrm{ab}}$ \\
\hline Month 8 & - & - & - & $4.2^{\mathrm{c}}$ & - & $4.8^{\mathrm{b}}$ & $3.8^{\mathrm{b}}$ & - & - & $4.7^{\mathrm{c}}$ \\
\hline \multicolumn{11}{|l|}{ Color ${ }^{3}$} \\
\hline Month 0 & $6.5^{\mathrm{a}}$ & $4.9^{\mathrm{a}}$ & $4.8^{\mathrm{a}}$ & $5.8^{\mathrm{a}}$ & $5.8^{\mathrm{a}}$ & $5.2^{\mathrm{a}}$ & $6.2^{\mathrm{a}}$ & $6.4^{\mathrm{ab}}$ & $5.4^{\mathrm{a}}$ & $4.7^{\mathrm{a}}$ \\
\hline Month 2 & $6.0^{\mathrm{a}}$ & $5.6^{\mathrm{a}}$ & $5.4^{\mathrm{ab}}$ & $6.2^{\mathrm{ab}}$ & $6.4^{\mathrm{a}}$ & $4.9^{\mathrm{a}}$ & $5.9^{\mathrm{a}}$ & $6.8^{\mathrm{b}}$ & $6.3^{\mathrm{a}}$ & $6.3^{\mathrm{a}}$ \\
\hline Month 4 & $5.4^{\mathrm{a}}$ & $6.2^{\mathrm{a}}$ & $6.9^{\mathrm{b}}$ & $8.5^{\mathrm{b}}$ & $6.4^{\mathrm{a}}$ & $5.8^{\mathrm{a}}$ & $4.6^{\mathrm{a}}$ & $4.5^{\mathrm{a}}$ & $5.3^{\mathrm{a}}$ & $6.4^{\mathrm{a}}$ \\
\hline Month 8 & - & - & - & $6.1^{\mathrm{a}}$ & - & $4.8^{\mathrm{a}}$ & $5.6^{\mathrm{a}}$ & - & - & $5.3^{\mathrm{a}}$ \\
\hline \multicolumn{11}{|l|}{ Glossiness $^{4}$} \\
\hline Month 0 & $3.6^{\mathrm{b}}$ & $4.9^{\mathrm{b}}$ & $5.2^{\mathrm{b}}$ & $4.9^{\mathrm{b}}$ & $3.8^{\mathrm{b}}$ & $2.8^{\mathrm{a}}$ & $2.9^{\mathrm{a}}$ & $3.9^{\mathrm{b}}$ & $5.6^{\mathrm{b}}$ & $5.0^{c}$ \\
\hline Month 2 & $1.5^{\mathrm{a}}$ & $2.4^{\mathrm{a}}$ & $1.4^{\mathrm{a}}$ & $3.4^{\mathrm{ab}}$ & $1.8^{\mathrm{ab}}$ & $3.8^{\mathrm{a}}$ & $3.2^{\mathrm{a}}$ & $3.0^{\mathrm{ab}}$ & $2.2^{\mathrm{a}}$ & $3.2^{\mathrm{b}}$ \\
\hline Month 4 & $0.2^{\mathrm{a}}$ & $1.3^{\mathrm{a}}$ & $1.3^{\mathrm{a}}$ & $2.8^{\mathrm{a}}$ & $0.9^{\mathrm{a}}$ & $2.8^{\mathrm{a}}$ & $3.2^{\mathrm{a}}$ & $2.2^{\mathrm{a}}$ & $1.5^{\mathrm{a}}$ & $1.6^{\mathrm{ab}}$ \\
\hline Month 8 & - & - & - & $2.0^{\mathrm{a}}$ & - & $1.8^{\mathrm{a}}$ & $3.1^{\mathrm{a}}$ & - & - & $1.5^{\mathrm{a}}$ \\
\hline \multicolumn{11}{|l|}{ Translucency $^{5}$} \\
\hline Month 0 & $\begin{array}{l}12 \\
.8^{\mathrm{a}}\end{array}$ & $12.3^{\mathrm{a}}$ & $12.8^{\mathrm{a}}$ & $12.4^{\mathrm{a}}$ & $12.4^{\mathrm{a}}$ & $12.0^{\mathrm{a}}$ & $12.2^{\mathrm{a}}$ & $12.9^{\mathrm{a}}$ & $11.9^{\mathrm{a}}$ & $12.1^{\mathrm{a}}$ \\
\hline Month 2 & $\begin{array}{l}11 \\
.9^{\mathrm{a}}\end{array}$ & $12.7^{\mathrm{a}}$ & $12.3^{\mathrm{a}}$ & $12.7^{\mathrm{a}}$ & $12.4^{\mathrm{a}}$ & $12.8^{\mathrm{a}}$ & $12.2^{\mathrm{a}}$ & $12.2^{\mathrm{ab}}$ & $11.9^{\mathrm{a}}$ & $12.0^{\mathrm{a}}$ \\
\hline Month 4 & $\begin{array}{l}11 \\
.4^{\mathrm{a}}\end{array}$ & $12.1^{\mathrm{a}}$ & $11.6^{\mathrm{a}}$ & $11.9^{\mathrm{a}}$ & $12.3^{\mathrm{a}}$ & $12.3^{\mathrm{a}}$ & $11.6^{\mathrm{a}}$ & $10.4^{\mathrm{a}}$ & $11.0^{\mathrm{a}}$ & $10.9^{\mathrm{ab}}$ \\
\hline Month 8 & - & - & - & $10.3^{\mathrm{a}}$ & - & $10.0^{\mathrm{a}}$ & $10.9^{\mathrm{a}}$ & - & - & $8.9^{\mathrm{b}}$ \\
\hline \multicolumn{11}{|c|}{ General Acceptability ${ }^{6}$} \\
\hline Month 0 & $9.3^{\mathrm{b}}$ & $9.0^{\mathrm{b}}$ & $10.0^{\mathrm{b}}$ & $8.5^{\mathrm{b}}$ & $10.0^{\mathrm{b}}$ & $9.2^{\mathrm{a}}$ & $9.8^{\mathrm{a}}$ & $10.7^{\mathrm{b}}$ & $9.6^{\mathrm{a}}$ & $8.8^{\mathrm{a}}$ \\
\hline Month 2 & $5.3^{\mathrm{a}}$ & $5.8^{\mathrm{a}}$ & $5.4^{\mathrm{a}}$ & $6.1^{\mathrm{ab}}$ & $5.6^{\mathrm{a}}$ & $7.0^{\mathrm{ab}}$ & $7.1^{\mathrm{a}}$ & $6.0^{\mathrm{a}}$ & $6.2^{\mathrm{b}}$ & $6.7^{\mathrm{ab}}$ \\
\hline Month 4 & $2.4^{\mathrm{a}}$ & $4.0^{\mathrm{a}}$ & $3.8^{\mathrm{a}}$ & $5.9^{\mathrm{ab}}$ & $4.4^{\mathrm{a}}$ & $6.9^{\mathrm{ab}}$ & $7.1^{\mathrm{a}}$ & $4.8^{\mathrm{a}}$ & $3.2^{\mathrm{c}}$ & $6.2^{\mathrm{ab}}$ \\
\hline Month 8 & - & - & - & $5.5^{\mathrm{a}}$ & - & $6.7^{\mathrm{a}}$ & $7.0^{\mathrm{a}}$ & - & - & $5.4^{\mathrm{a}}$ \\
\hline \multicolumn{11}{|c|}{ 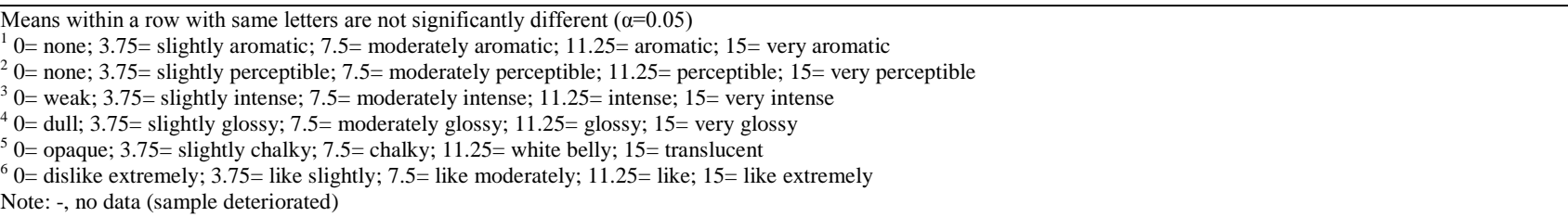 } \\
\hline
\end{tabular}

On the other hand, sensory evaluation of cooked brown rice samples revealed a significant decrease in aroma during storage and cohesiveness at 2 months; while a significant increase in off-odor and off-taste both at 8 months, except that of untreated sample (Table 8). Previous researches attributed off-flavor (off-taste) and off-odor development to high levels of free fatty acids or phenolics compounds (Barber, 1972; Tsugita et al., 1983; Molteberg et al., 1996; Zhou et al., 1999; Heinio et al., 2002); hence sensory evaluation results were consistent with the chemical analysis. No significant change in cooked brown rice attribute score of each sample on glossiness, cohesiveness, tenderness, and taste was observed during storage. This observation is different from the reports of several studies that texture of aged (stored) cooked milled becomes harder (Moritaka et al., 1971; Villareal et al., 1976; Indudhara et al., 1978; Chrastil, 1990), where most of the researchers utilize a machine to objectively measure cooked rice hardness. However, Juliano et al., (1969) observed similar taste panel scores for tenderness, cohesiveness and gloss for stored (6 months) milled rice, suggesting no appreciably change in the texture of the resulting cooked rice. General acceptability score of each cooked brown rice sample significantly decrease during storage, except that of MW 90sec. By the second month, a significant downshift in general acceptability scores was noted on untreated sample, DH 15 min and MW 30sec; and continued to significantly decrease up to 4 months, except that of DH $25 \mathrm{~min}, \mathrm{MW} 90 \mathrm{sec}$, WH $30 \mathrm{sec}$ and WH 60sec. After 4 months of storage, only treated brown rice sample with longer exposure times (DH 25min, MW 90sec and WH 90sec), including MW 60sec, lasted and remained acceptable (liked moderately) even up to eight months of storage (Figure 2).

Table 8 Sensory attribute of cooked brown rice samples at different treatments during storage

\begin{tabular}{|c|c|c|c|c|c|c|c|c|c|c|}
\hline \multirow{2}{*}{ Attributes } & \multicolumn{10}{|c|}{ Sample, Mean Score } \\
\hline & Control & DH 10min & DH 15min & DH 25min & MW 30sec & MW 60sec & MW 90sec & WH 30sec & WH 60sec & WH 90sec \\
\hline \multicolumn{11}{|l|}{ Aroma $^{1}$} \\
\hline Month 0 & $4.7^{\mathrm{a}}$ & $3.6^{\mathrm{a}}$ & $3.2^{\mathrm{a}}$ & $3.6^{\mathrm{a}}$ & $4.5^{\mathrm{a}}$ & $3.4^{\mathrm{b}}$ & $3.5^{\mathrm{a}}$ & $3.6^{\mathrm{ab}}$ & $4.0^{\mathrm{b}}$ & $5.6^{\mathrm{b}}$ \\
\hline Month 2 & $4.9^{\mathrm{a}}$ & $4.7^{\mathrm{a}}$ & $5.1^{\mathrm{b}}$ & $3.7^{\mathrm{a}}$ & $3.3^{\mathrm{a}}$ & $2.4^{\mathrm{ab}}$ & $3.6^{\mathrm{a}}$ & $4.9^{\mathrm{b}}$ & $2.9^{\mathrm{ab}}$ & $2.6^{\mathrm{a}}$ \\
\hline Month 4 & $2.1^{\mathrm{b}}$ & $3.4^{\mathrm{a}}$ & $1.7^{\mathrm{c}}$ & $2.5^{\mathrm{ab}}$ & $3.0^{\mathrm{a}}$ & $2.1^{\mathrm{ab}}$ & $1.3^{\mathrm{b}}$ & $2.2^{\mathrm{a}}$ & $1.5^{\mathrm{a}}$ & $2.4^{\mathrm{a}}$ \\
\hline Month 8 & - & - & - & $1.2^{\mathrm{b}}$ & - & $1.2^{\mathrm{a}}$ & $1.7^{\mathrm{ab}}$ & - & - & $1.6^{\mathrm{a}}$ \\
\hline \multicolumn{11}{|l|}{ Off-odor ${ }^{2}$} \\
\hline Month 0 & $0.0^{\mathrm{a}}$ & $0.2^{\mathrm{a}}$ & $0.0^{\mathrm{a}}$ & $0.0^{\mathrm{a}}$ & $0.0^{\mathrm{a}}$ & $0.0^{\mathrm{a}}$ & $0.0^{\mathrm{a}}$ & $0.0^{\mathrm{a}}$ & $0.0^{\mathrm{a}}$ & $0.0^{\mathrm{a}}$ \\
\hline Month 2 & $0.0^{\mathrm{a}}$ & $0.2^{\mathrm{a}}$ & $0.0^{\mathrm{a}}$ & $0.2^{\mathrm{a}}$ & $0.0^{\mathrm{a}}$ & $0.1^{\mathrm{a}}$ & $0.0^{\mathrm{a}}$ & $0.0^{\mathrm{a}}$ & $0.0^{\mathrm{a}}$ & $0.0^{\mathrm{a}}$ \\
\hline Month 4 & $0.3^{\mathrm{a}}$ & $1.0^{\mathrm{a}}$ & $0.4^{\mathrm{a}}$ & $0.7^{\mathrm{a}}$ & $0.2^{\mathrm{a}}$ & $0.8^{\mathrm{ab}}$ & $1.3^{\mathrm{b}}$ & $0.3^{\mathrm{a}}$ & $0.3^{\mathrm{a}}$ & $0.3^{\mathrm{a}}$ \\
\hline Month 8 & - & - & - & $2.4^{\mathrm{b}}$ & - & $2.2^{\mathrm{b}}$ & $1.1^{\mathrm{ab}}$ & - & - & $1.7^{\mathrm{b}}$ \\
\hline \multicolumn{11}{|l|}{ Gloss $^{3}$} \\
\hline Month 0 & $7.0^{\mathrm{b}}$ & $6.8^{\mathrm{a}}$ & $6.6^{\mathrm{a}}$ & $7.8^{\mathrm{b}}$ & $8.5^{\mathrm{b}}$ & $6.1^{\mathrm{a}}$ & $7.5^{\mathrm{b}}$ & $7.5^{\mathrm{b}}$ & $8.3^{\mathrm{a}}$ & $9.3^{\mathrm{b}}$ \\
\hline Month 2 & $5.4^{\mathrm{ab}}$ & $6.2^{\mathrm{a}}$ & $5.3^{\mathrm{a}}$ & $7.8^{\mathrm{b}}$ & $6.9^{\mathrm{ab}}$ & $6.0^{\mathrm{a}}$ & $5.3^{\mathrm{ab}}$ & $4.8^{\mathrm{a}}$ & $7.0^{\mathrm{a}}$ & $6.3^{\mathrm{a}}$ \\
\hline
\end{tabular}




\begin{tabular}{|c|c|c|c|c|c|c|c|c|c|c|}
\hline Month 4 & $4.1^{\mathrm{a}}$ & $5.2^{\mathrm{a}}$ & $5.0^{\mathrm{a}}$ & $5.2^{\mathrm{a}}$ & $4.6^{\mathrm{a}}$ & $4.1^{\mathrm{a}}$ & $4.8^{\mathrm{a}}$ & $5.7^{\mathrm{ab}}$ & $4.2^{\mathrm{b}}$ & $4.7^{\mathrm{a}}$ \\
\hline Month 8 & - & - & - & $5.1^{\mathrm{a}}$ & - & $5.0^{\mathrm{a}}$ & $5.7^{\mathrm{ab}}$ & - & - & $4.2^{\mathrm{a}}$ \\
\hline \multicolumn{11}{|l|}{ Cohesiveness ${ }^{4}$} \\
\hline Month 0 & $6.8^{\mathrm{b}}$ & $6.5^{\mathrm{a}}$ & $6.8^{\mathrm{b}}$ & $9.0^{\mathrm{b}}$ & $8.1^{\mathrm{b}}$ & $8.4^{\mathrm{b}}$ & $7.4^{\mathrm{b}}$ & $7.8^{\mathrm{b}}$ & $7.1^{\mathrm{b}}$ & $8.1^{\mathrm{b}}$ \\
\hline Month 2 & $3.9^{\mathrm{a}}$ & $5.0^{\mathrm{a}}$ & $4.4^{\mathrm{a}}$ & $8.1^{\mathrm{b}}$ & $5.8^{\mathrm{a}}$ & $5.1^{\mathrm{a}}$ & $4.5^{\mathrm{a}}$ & $3.8^{\mathrm{a}}$ & $5.6^{\mathrm{ab}}$ & $5.5^{\mathrm{a}}$ \\
\hline Month 4 & $4.0^{\mathrm{a}}$ & $4.9^{\mathrm{a}}$ & $4.5^{\mathrm{a}}$ & $4.5^{\mathrm{a}}$ & $5.1^{\mathrm{a}}$ & $5.5^{\mathrm{a}}$ & $5.3^{\mathrm{ab}}$ & $5.2^{\mathrm{a}}$ & $4.4^{\mathrm{a}}$ & $4.4^{\mathrm{a}}$ \\
\hline Month 8 & - & - & - & $5.5^{\mathrm{a}}$ & - & $4.2^{\mathrm{a}}$ & $3.4^{\mathrm{a}}$ & - & - & $5.0^{\mathrm{a}}$ \\
\hline \multicolumn{11}{|l|}{ Tenderness ${ }^{5}$} \\
\hline Month 0 & $5.7^{\mathrm{a}}$ & $6.1^{\mathrm{a}}$ & $5.5^{\mathrm{a}}$ & $7.7^{\mathrm{a}}$ & $7.9^{\mathrm{a}}$ & $6.1^{\mathrm{ab}}$ & $4.9^{\mathrm{a}}$ & $5.0^{\mathrm{a}}$ & $6.6^{\mathrm{a}}$ & $6.4^{\mathrm{ab}}$ \\
\hline Month 2 & $6.9^{\mathrm{a}}$ & $7.1^{\mathrm{a}}$ & $6.4^{\mathrm{a}}$ & $6.2^{\mathrm{a}}$ & $7.6^{\mathrm{a}}$ & $5.2^{\mathrm{a}}$ & $5.3^{\mathrm{a}}$ & $7.8^{\mathrm{a}}$ & $5.3^{\mathrm{a}}$ & $5.9^{\mathrm{a}}$ \\
\hline Month 4 & $7.4^{\mathrm{a}}$ & $5.8^{\mathrm{a}}$ & $7.4^{\mathrm{a}}$ & $7.8^{\mathrm{a}}$ & $7.9^{\mathrm{a}}$ & $6.8^{\mathrm{ab}}$ & $6.5^{\mathrm{a}}$ & $7.1^{\mathrm{a}}$ & $7.0^{\mathrm{a}}$ & $8.5^{\mathrm{ab}}$ \\
\hline Month 8 & - & - & - & $8.4^{\mathrm{a}}$ & - & $8.4^{\mathrm{b}}$ & $7.5^{\mathrm{a}}$ & - & - & $8.8^{\mathrm{b}}$ \\
\hline \multicolumn{11}{|l|}{ Taste $^{6}$} \\
\hline Month 0 & $3.7^{\mathrm{b}}$ & $2.7^{\mathrm{a}}$ & $2.9^{\mathrm{a}}$ & $3.0^{\mathrm{a}}$ & $3.6^{\mathrm{b}}$ & $3.4^{\mathrm{a}}$ & $3.3^{\mathrm{b}}$ & $2.9^{\mathrm{a}}$ & $2.9^{\mathrm{a}}$ & $3.1^{\mathrm{a}}$ \\
\hline Month 2 & $1.9^{\mathrm{a}}$ & $1.9^{\mathrm{b}}$ & $2.8^{\mathrm{a}}$ & $3.0^{\mathrm{a}}$ & $2.4^{\mathrm{ab}}$ & $2.8^{\mathrm{a}}$ & $3.0^{\mathrm{ab}}$ & $2.8^{\mathrm{a}}$ & $2.1^{\mathrm{a}}$ & $2.1^{\mathrm{a}}$ \\
\hline Month 4 & $1.5^{\mathrm{a}}$ & $3.2^{\mathrm{ab}}$ & $3.2^{\mathrm{a}}$ & $2.9^{\mathrm{a}}$ & $1.2^{\mathrm{a}}$ & $0.5^{\mathrm{a}}$ & $1.0^{\mathrm{a}}$ & $3.1^{\mathrm{a}}$ & $2.1^{\mathrm{a}}$ & $2.5^{\mathrm{a}}$ \\
\hline Month 8 & - & - & - & $1.4^{\mathrm{a}}$ & - & $2.0^{\mathrm{ab}}$ & $2.1^{\mathrm{ab}}$ & - & - & $1.8^{\mathrm{a}}$ \\
\hline \multicolumn{11}{|l|}{ Off-taste ${ }^{7}$} \\
\hline Month 0 & $0.3^{\mathrm{a}}$ & $0.0^{\mathrm{a}}$ & $0.0^{\mathrm{a}}$ & $0.0^{\mathrm{a}}$ & $0.2^{\mathrm{a}}$ & $0.2^{\mathrm{a}}$ & $0.0^{\mathrm{a}}$ & $0.6^{\mathrm{a}}$ & $0.0^{\mathrm{a}}$ & $0.3^{\mathrm{a}}$ \\
\hline Month 2 & $0.3^{\mathrm{ab}}$ & $0.9^{\mathrm{b}}$ & $0.2^{\mathrm{a}}$ & $0.5^{\mathrm{a}}$ & $0.4^{\mathrm{a}}$ & $0.4^{\mathrm{a}}$ & $0.0^{\mathrm{a}}$ & $0.4^{\mathrm{a}}$ & $0.1^{\mathrm{a}}$ & $0.8^{\mathrm{a}}$ \\
\hline Month 4 & $1.7^{\mathrm{b}}$ & $0.2^{\mathrm{ab}}$ & $0.2^{\mathrm{a}}$ & $0.2^{\mathrm{a}}$ & $0.0^{\mathrm{a}}$ & $0.6^{\mathrm{a}}$ & $0.3^{\mathrm{a}}$ & $0.1^{\mathrm{a}}$ & $0.4^{\mathrm{a}}$ & $0.7^{\mathrm{a}}$ \\
\hline Month 8 & - & - & - & $2.3^{\mathrm{b}}$ & - & $1.7^{\mathrm{b}}$ & $1.8^{\mathrm{b}}$ & - & - & $1.3^{\mathrm{a}}$ \\
\hline \multicolumn{11}{|c|}{ General Acceptability $^{8}$} \\
\hline Month 0 & $9.8^{\mathrm{b}}$ & $8.0^{\mathrm{b}}$ & $8.9^{\mathrm{b}}$ & $9.5^{\mathrm{b}}$ & $9.9^{\mathrm{b}}$ & $8.2^{\mathrm{b}}$ & $8.0^{\mathrm{a}}$ & $7.8^{\mathrm{a}}$ & $8.3^{\mathrm{a}}$ & $9.1^{\mathrm{b}}$ \\
\hline Month 2 & $5.0^{\mathrm{a}}$ & $6.0^{\mathrm{ab}}$ & $6.2^{\mathrm{a}}$ & $7.4^{\mathrm{ab}}$ & $5.7^{\mathrm{a}}$ & $5.7^{\mathrm{ab}}$ & $6.1^{\mathrm{a}}$ & $7.0^{\mathrm{a}}$ & $7.4^{\mathrm{a}}$ & $7.4^{\mathrm{ab}}$ \\
\hline Month 4 & $4.6^{\mathrm{a}}$ & $5.5^{\mathrm{a}}$ & $4.9^{\mathrm{a}}$ & $7.5^{\mathrm{ab}}$ & $5.6^{\mathrm{a}}$ & $4.7^{\mathrm{a}}$ & $6.4^{\mathrm{a}}$ & $6.1^{\mathrm{a}}$ & $6.7^{\mathrm{a}}$ & $6.3^{\mathrm{a}}$ \\
\hline Month 8 & - & - & - & $5.4^{\mathrm{a}}$ & - & $5.7^{\mathrm{a}}$ & $5.7^{\mathrm{a}}$ & - & - & $6.7^{\mathrm{a}}$ \\
\hline
\end{tabular}

Means within a row with same letters are not significantly different $(\alpha=0.05)$

${ }^{1} 0=$ none; $3.75=$ slightly aromatic $; 7.5=$ moderately aromatic; $11.25=$ aromatic; $15=$ very aromatic

${ }^{2} 0=$ none; $3.75=$ slightly perceptible; $7.5=$ moderately perceptible; $11.25=$ perceptible; $15=$ very perceptible

${ }^{3} 0=$ dull; $3.75=$ slightly glossy; $7.5=$ moderately glossy; $11.25=$ glossy; $15=$ very glossy

${ }^{4} 0=$ separated; $3.75=$ slightly cohesive $; 7.5=$ moderately cohesive; $11.25=$ cohesive $; 15=$ very cohesive

${ }^{5} 0=$ hard; $3.75=$ slightly tender; $7.5=$ moderately tender; $11.25=$ tender; $15=$ very tender

${ }^{6} 0=$ bland; $3.75=$ slightly tasty; $7.5=$ moderately tasty; $11.25=$ tasty; $15=$ very tasty

${ }^{7} 0=$ none; $3.75=$ slightly perceptible; $7.5=$ moderately perceptible; $11.25=$ perceptible; $15=$ very perceptible

${ }^{8} 0=$ dislike extremely; $3.75=$ like slightly; $7.5=$ like moderately; $11.25=$ like; $15=$ like extremely

Note: -, no data (sample deteriorated)
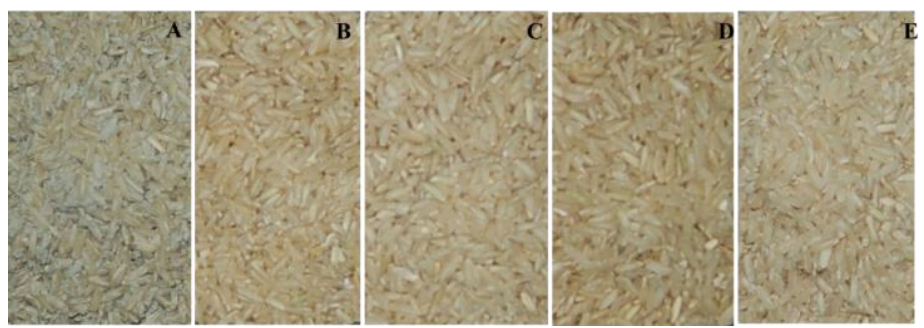

Figure 2 Eight-month old brown rice. Untreated brown rice (A) considerably deteriorated after 2 months of storage compared to 8-month old brown rice exposed to DH for $25 \mathrm{~min}(\mathrm{~B})$, MW for $90 \mathrm{sec}(\mathrm{C})$, WH for $90 \mathrm{sec}(\mathrm{D})$ and $\mathrm{MW}$ for $60 \sec (\mathrm{E})$.

\section{CONCLUSION}

Findings from this study established heat and microwave treatment conditions that could effectively inactivate lipase enzyme to consequently stabilize brown rice against rancidity, without affecting its antioxidant activity for up to 8 months of storage. Improvement of brown rice storability through these optimum treatment conditions was demonstrated through monitoring the changes in chemical properties (free fatty acids, phenolics content and antioxidant activity), and raw and cooked sensory attributes during storage. Application of these technologies to pilot-scale and subsequently to commercial-scale is being conducted.
Acknowledgments: The authors would like to thank Prof. Dr. Adelina P. Valdez and Prof. Marilene C. Hipolito of the Department of Chemistry, College of Arts and Sciences, Central Luzon State University, Science City of Muñoz, Nueva Ecija, Philippines for their comments and suggestions to improve this manuscript.

\section{REFERENCES}

AMERICAN ASSOCIATION OF CEREAL CHEMISTS. 2000. AACC Method 44-15A. Moisture-Air-Oven Methods. Approved Methods of the American Association of Cereal Chemists, St Paul, MN, USA,Vol. 2, 4 p.

ADOM, K.K., LIU, R.H. 2002. Antioxidant activities of grains. J. Agric. Food Chem, 50, 6182-6187. http://dx.doi.org/10.1021/jf0205099

AFOAKWAH, A.N., OWUSU, J., ADOMAKO, C., TEYE, E. 2012. Microwave Assisted Extraction (MAE) of antioxidant constituents in plant materials. Global Journal of Bio-Science and Biotechnology, 1 (2), 132-140.

BARBER, S. 1972. Milled rice and changes during aging. In: Rice Chemistry and Technology, First Ed..; Houston, D.F., Ed., American Association of Cereal Chemistry, Eagan, MN, USA, 215-263.

CHAMPANGE, E.T., HRON SR, R.J., ABRAHAM, G. 1991. Stabilizing brown rice products by acqueous ethanol ethanol extraction. Cereal Chemistry, 67, 267271

CHAMPAGNE, E.T., HRON SR, R.J. 1992. Stabilizing brown rice to lipolytic hydrolysis by ethanol vapors. Cereal Chemistry, 69 (2),152-156.

CHAMPAGNE, E.T., HRON SR, R.J. 1993. Utilizing ethanol containing an antioxidant or chelator to produce stable brown rice products. Cereal Chemistry, 70, 562-567.

CHAMPAGNE, E.T., GRIMME, C.C. 1995. Stabilization of brown rice products using ethanol vapors as an antioxidant delivery system. Cereal Chemistry, 72 (3), 255-258. 
CHRASTIL, J. 1990. Protein-starch interaction in rice grains. Influence of storage on oryzenin and starch. Journal of Agricultural and Food Chemistry, 38, 1804-1809. http://dx.doi.org/10.1021/jf00099a005

CORPUZ, H.M., ABLAZA, M.J.C., ROMERO, M.V. 2010. Excellent brown rice from suitable varieties. The Philippine Journal of Crop Science, ISSN 0115463X, Vol. 35 (S1). Available at http://agris.fao.org/agrissearch/search.do?recordID $=\mathrm{PH} 2010000575$

CUENDET, L.S., LARSON, E., NORRIS, C.G., GEDDES, W.F. 1954. The influence of moisture content and other factors on the stability of wheat flours at $37.5^{\circ} \mathrm{C}$. Cereal Chemistry, 31, 362-389.

CUYNO, R.V. 2003. The national campaign to combat hidden hunger though brown rice. (Paper presented during Consultative Meeting on Nutritional Aspect of Brown Rice, Sept. 2003, at Food and Nutritional Research Institute, Manila, Philippines).

DAMODARAN, S. 1996. Amino acids, peptides, and proteins. In: Fennema O.R. ed., Food Chemistry : New York, Marcel Dekker, 321-429.

DAR, B.N., SHARMA, S. 2011. Total phenolic content of cereal brans using conventional and microwave assisted extraction. American Journal of Food Technology, 6 (12), 1045-1053. http://dx.doi.org/10.3923/ajft.2011.1045.1053

DYKES, L., ROONEY, L.W. 2007. Phenolic compounds in cereal grains and their health benefits. Cereal Foods World, 52 (3),105-111. http://dx.doi.org/10.1094/cfw-52-3-0105

HARIDAS RAO, P., KUMAR, G.V., RANGA RAO, G.C.P., SHURPALEKAR, S.R. 1980. Studies on the stabilization of wheat germ. Lebensm. Wiss. Technology, 13, 302-307

HEINIÖ, R.L., LEHTINEN, P., OKSMAN-CALDENTEY, K.M., POUTANEN K. 2002. Differences between sensory profiles and development of rancidity during long-term storage of native and processed oat. Cereal Chemistry, 79 (3), 367-375. http://dx.doi.org/10.1094/cchem.2002.79.3.367

INDUDHARA SWAMY Y.M., SOWBHAGYA C.M., BHATTACHARYA, K.R. 1978. Changes in physicochemical properties of rice with ageing. J. Sci. Food Agric., 29, 627-639. http://dx.doi.org/10.1002/jsfa.2740290709

IQBAL, S., BHANGE, M.I., ANWAR, F. 2005. Antioxidant properties and components of some commercially available varieties of rice bran in pakistan Food Chemistry, 93, 265-272. http://dx.doi.org/10.1016/j.foodchem.2004.09.024 JULIANO, B.O. 1985. Rice Chemistry and Technology (2nd Ed.). American Association of Cereal Chemists, St Paul, MN, USA: American Association of Cereal Chemists, Inc. ISBN 0-913250-41-4. http://dx.doi.org/10.1016/03088146(87)90086-0

JULIANO, B.O., NAZARENO, M.B., RAMOS, N.B. 1969. Properties of waxy and isogenic nonwaxy rices differing in starch gelatinization temperature. $J$ Agric. Foo Chem., 17, 1364-1369. http://dx.doi.org/10.1021/jf60166a062 KESTER, E.B. 1951. Stabilization of brown rice, US patent 2,538,007

KRUGER, J. E., REED, G. 1988. Enzymes and color. In Pomeranz Y. (ed.) Wheat Chemistry and Technology, 3rd Ed., Vol. 1. American

Association of Cereal Chemists International, St. Paul, MN, USA, 441-500.

KWON, D.Y., RHEE, J.S. 1986. A simple and rapid colorimetric method for determination of free fatty acids for lipase assay. Journal of American Oil Chemist Society, 63(1), 89-92. http://dx.doi.org/10.1007/bf02676129

LEHTINENT, P., LAAKSO, S. 2004. Role of lipid reactions in quality of oat products. Journal of Agricultural and Food Science, 13, 88-99. http://dx.doi.org/10.2137/1239099041838085

LEHTINENT, P., KIILIAINENT, K., LEHTOMAKI, I., LAAKSO, S. 2003.

Effect of heat treatment on lipid stability in processed oats. Journal of Cereal Science, 37, 215-221. http://dx.doi.org/10.1006/jcrs.2002.0496

MCCABE, D. 1976. Process for preparing a quick-cooking brown rice and the resulting product, US patent 3,959,515.

MOLTEBERG, E.L., MAGNUS, E.M., BJØRGE, J.M., NILSSON, A. 1996. Sensory and chemical studies of lipid oxidation in raw and heat-treated oat flours. Cereal Chemistry, 73, 579-587.

MORITAKA, S., SAWADA, K., YASUMATSU, K. 1971. Studies on Cereals. VI. Effect of fat extraction on rice quality and storage deterioration of defatted rice. Eiyo To Shokuryo, 24, 457-460.

ORY, R.L., DELUCCA, A.J., ST. ANGELO, A.J., DUPUY, H.P. 1980. Storage quality of brown rice as affected by packaging with and without carbon dioxide. Journal of Food Protocols, 43, 929.

OUFNAC, D.S. 2006. Determination of antioxidant capacity in corn germ, wheat germ and wheat bran using solvent and microwave-assisted solvent extraction Louisiana State University (MS Thesis). Available at http://etd.lsu.edu/docs/available/etd-11152006-

162056/unrestricted/davidsoufnacthesis.pdf

RAMEZANZADEH, F.M., RAO, R.M., WINDHAUSER, M., PRINYAWIWATKUL, W., TULLEY, R., MARSHALL, W.E. 1999. Prevention of hydrolytic rancidity in rice bran during storage. Journal of Agricultural and Food Chemistry, 47 (8), 3050-3052. http://dx.doi.org/10.1021/jf981335r ROSE, D. J., LOGDEN, V.M., DUNN, L., PIKE, O.A. 2008. Enhanced lipid stability in whole wheat flour by lipase inactivation and antioxidant retention. Cereal Chemistry, 85(2), 218-223. http://dx.doi.org/10.1094/cchem-85-2-0218 ROSE, D. J., PIKE, O.A. 2006. A simple method to measure lipase activity in wheat and wheat bran as an estimation of storage quality. Journal of American Oil Chemist Society, 83(5), 415-419. http://dx.doi.org/10.1007/s11746-006-12200

ROTHE, M. 1967. Hitzeinaktivierung von Ezymen im Zusammenhang mit der Stabilisierung von Reiskleie. In: Proc. Meeting, Int. Problems on Modern Cereal Processing and Chemistry 3rd. Part I. Milling. Rice Processing. Inst. Getreideverarbeitung, Bergholz-Rehbrucke, G.D.R., 146-151.

SANTROPRETE, G. 1980. Preservation of slightly milled rice. Riso 29:61.

SHARP, R.N., TIMME, L.K. 1986. Effects of storage time, storage temperature, and packaging method on shelf life of brown rice. Cereal Chemistry, 63 (3), 247 251

TSUGITA, T., OHTA, T., KATO, H. 1983. Cooking flavor and texture of rice stored under different conditions. Agric. Biol. Chem., 47 (3), 543-549. http://dx.doi.org/10.1080/00021369.1983.10865684

VAN ATTA, G.R., KESTER, E.B., OLCOTT, H.S. 1952. Method of stabilizing rice products, US patent 2,585,978.

VETRIMANI, R., HARIDAS RAO, P. 1990. Changes in the functional characteristics of wheat during soaking and subsequent germination. Journal of Food Science and Technology, 27, 332-335.

VILLAREAL, R.M., RESURRECCION, A.P., SUZUKI, L.B., JULIANO, B.O. 1976. Changes in physicochemical properties of rice during storage. Staerke, 38 , 88-94. http://dx.doi.org/10.1002/star.19760280304

ZHOU, M., ROBARDS, K., GLENNIE-HOLMES, M., HELLIWELL, S. 1999. Analysis of volatile compounds and their contribution to flavor in cereals. Journal of Agricultural and Food Chemistry, 10, 3941-3953. http://dx.doi.org/10.1021/jf9904281 